doi: $10.26529 /$ cepsj.499

\title{
Information Communication Technologies in Teaching English as a Foreign Language: Analysing EFL Teachers' TPACK in Czech Elementary Schools
}

Dev Raj Paneru ${ }^{1}$

$\approx \quad$ This qualitative study was carried out in five different elementary schools in the Czech Republic. It aimed to investigate how English as Foreign Language teachers developed teaching competence and practised information communication technology integration in classroom teaching. To this end, this study employed the idea of a Technology Pedagogy and Content Knowledge -TPACK -in-Action Model. It advocates a 'learning by doing' approach on (social) construction to better understand how teachers develop technological and/or computer-assisted language learning competency for teaching and practice in an English as a Foreign Language environment. Under this model, this study conducted qualitative analysis and found two different approaches in practice, which were categorised as Formal Practice and Functional Practice. The former involved a conservative mechanical practice of technology use in language teaching whereas the latter involved it in terms of (social) construction. According to analyses based on conservative practices, teachers expressed that mechanical TPACK in association with technology in classes limited the transmission of mechanical knowledge from English texts. In Functional Practice, however, teachers drawing upon alternative learning interactions expressed positive transformation results from TPACK, associated with the use of technologies integrated into class instructions as a collaborative tool for learning models. In these latter integrated practices, teachers' perceptions, practices, and reflections in combining technologies in an English as a Foreign Language environment, as new literacy skills, identified an increase in the learner's creative potential.

Keywords: technology, EFL, teacher competence, transformative learning, teaching practices

1 Department of Educational Sciences, Faculty of Arts, Masaryk University, The Czech Republic; devrajpaneru1@gmail.com. 


\section{Informacijsko-komunikacijske tehnologije pri poučevanju angleščine kot tujega jezika: analiza TPACK pri učiteljih angleščine kot tujega jezika $\mathrm{v}$ čeških osnovnih šolah}

Dev Raj Paneru

$\approx$ Kvalitativna raziskava je bila izvedena v petih osnovnih šolah na Češkem. Namen raziskave je ugotoviti, kako so učitelji angleščine kot tujega jezika razvili kompetence poučevanja $\mathrm{z}$ informacijsko-komunikacijsko tehnologijo in kako so to vključevali v poučevanje. $S$ tem namenom je študija privzela idejo tehnološko-pedagoško vsebinskega znanja (Technological Pedagogical Content Knowledge - TPACK- in-ActionModel). Ta model spodbuja pristop k učenju skozi prasko kot (socialni) konstrukciji z namenom izboljšanja razumevanja, kako učitelji razvijajo kompetence tehnološkega in/ali računalniško podprtega poučevanja angleščine kot tujega jezika. Na podlagi tega modela je bila v okviru študije izvedena kvalitativna analiza, ki je pokazala dva različna pristopa pri pouku, ki sta bila kategorizirana kot "formalna praksa in »funkcionalna praksa«. Prvi pristop vključuje konservativno mehansko uporabo tehnologije pri poučevanju jezika, drugi pa rabo tehnologije vključuje v smislu (socialne) konstrukcije. Analiza konservativnih praks kaže, da so učitelji izrazili, da mehanski TPACK v povezavi s tehnologijo $\mathrm{v}$ razredu omejuje prenos mehanskega znanja iz angleških besedil. Za funkcionalno prakso pa je značilno, da so učitelji, ki so se opirali na alternativne učne interakcije, izrazili pozitivne transformacijske izide TPACK-a, povezane $z$ integracijo tehnologije kot sodelovalnega orodja učnih modelov v pouk. V okviru teh pristopov so percepcije, prakse in refleksije učiteljev o kombiniranju tehnologij pri poučevanju angleščine kot tujega jezika kot nove opismenjevalne veščine zaznale porast ustvarjalnega potenciala učencev.

Ključne besede: tehnologija, angleščina kot tuji jezik, kompetence učiteljev, transformativno učenje, poučevalne prakse 


\section{Introduction}

This study was carried out in five different elementary schools in the Czech Republic. It aimed to investigate how English as a Foreign Language (EFL) teachers developed Information Communication Technologies (ICT) and/or Computer Assisted Language Learning (CALL) competency and integrated them into EFL classroom teaching. To this end, this study employed Tai's (2015) idea of the TPACK-in-Action model. It is based on Technology Pedagogy and Content Knowledge (TPACK, Koehler, \& Mishra, 2009). It advocates a 'learning by doing' approach on (social) construction to better understand how EFL teachers develop technology or CALL competency and integrate into an EFL environment on constructing learning for communication skills.

In view of the fast pace of the changes in the school education caused by the emerging of digital systems impacting teaching-learning practices, new perspectives have emerged in transforming teacher ${ }^{2}$ competence for better student learning (EDiTE, 2015), while defining European teacher professionalism (Schratz, 2014). Transformative teacher learning as consistent with teacher's ${ }^{3}$ ICT and/or CALL competencies has been putting pressure on EFL education and teachers in the European schools. This is a significant issue connecting EFL teachers in the Czech school context, where fast-changing digital systems have an impacting role on developing teaching with new competencies, practices and perspectives in addressing communication skills (Nekvapil \& Sherman, 2009).

Pursuing the emerging perspectives, the researchers on language teacher education (TE), as pointed out in Tai (2015), explore TPACK-in-Action as a comprehensive learning model to study how EFL teachers develop CALL competency and practice in class. In this regard, studies not only report the importance of ICT for improving students' learning but also identify technology/ CALL experience or competency as a crucial component with which teachers need to be equipped with for the reality of the globally networked EFL classroom, as cited in Tour (2015).

Grasping this emerging trend in a globally expanding EFL education scenario, the studies as noted in Warschauer (2000) find that teacher competence that limits itself to cognitive CALL also limits the EFL teacher to mechanistic educational practice, thereby making it an inadequate teaching model

2 Teacher (teaching) competence/s in this study stands for teacher education with total criteria, e.g., TPACK of which ICT or CALL competency is one component.

3 Teacher's ICT and/or CALL competency/ies implies teacher's ICT or CALL knowledge, skills, experiences and practices as related to their integration in class. However, in some situations, ICT or CALL competency/ies, teacher's teaching competence/s as well as TPACK (competence) are also used interchangeably. 
for the $21^{\text {st }}$ century EFL class. At this point, some studies also draw upon ICT courses as being essential for enhancing EFL teacher competences. However, scholars in line with Godwin-Jones (2010) point out more compelling issues. They further assert that technology courses geared to EFL teachers' operating ability skills, rather than developing the teacher competences in real action, end up limiting it to mechanistic educational outcomes (Dockstader, 1999).

Thus, as an alternative, considering EFL teacher's CALL competency on social construction, scholars bring forward the concept of developing TPACKin-Action as a comprehensive learning model, as discussed in Tai (2015). According to this 'learning by doing' model, researchers describe EFL teacher competence/s not merely in teacher's formal and technological knowledge and practice for passing on knowledge. Instead, extending further, they represent it interactively in the teacher's innovative concepts, skills and practices of integrating technologies in collaborative actions in real EFL class context. In other words, the researchers assert EFL teacher competences in terms of TPACK in interactional collaborative practices on (social) construction.

Although TPACK literature is a comprehensive framework, as EFL teacher education is limited to survey questions, self-reported interviews and limitedly focused observations capturing teacher competencies, TPACK has yet to be developed in various dimensions (Ekrem \& Cakir, 2014). In the Czech education system, EFL researchers, in line with digital concepts, for example, study teacher competency and the practice of ICT and/or CALL in mechanistic schemes rather than allowing for TPACK as a comprehensive learning model (Grečnerová, 2015; OECD, 2003). Additionally, focused research on the TPACK framework is too sparse, considering EFL teaching practices in the Czech school context. Moreover, as the studies on TPACK are limited in terms of teachers' perceptions and practices, teachers' reflections on CALL competency and integration in EFL class on collaborative design (van Lier, 1996) have yet to be explored.

Thus, this study using the TPACK framework on qualitative phenomenological approach research design investigates how EFL teachers in Czech elementary schools have developed ICT and/or CALL competency and integrated it in real class practice. Regarding this, I first provide the concept of TPACK as a comprehensive learning framework. In its analysis, I specify the qualitative phenomenological approach research methodology or design. Then, in the result section, findings are stated in EFL teachers' competency and practice of ICT integration in EFL classes on developing TPACK in action followed by discussions of findings, and the conclusion. 


\section{The TPACK Framework}

The importance of the teacher's classroom teaching competence and practice of ICT integration in bringing along innovative concepts in the teaching-learning process of fast-paced digital education has been an engaging issue. However, its concepts and practices have rarely been consistent across pedagogical lines. For example, on the one hand, EFL researchers following Shulman's line conceptualise teacher competence on the teacher's expertise of the English language and its psychological knowledge. Others, also considering digital aspects, capture teacher competence in teacher's mechanistic knowledge as in Stensaker, Maassen, Borgan, Oftebro, and Karseth (2007) who discuss the teacher's skills in operating digital media and other devices. However, no further reference is made to the various interconnected dimensions involving learning, teaching, and technology.

On the other hand, contemporary researchers have described teachers' teaching competence and practice of ICT integration in class from the TPACK perspective. As a concept, modifying Shulman's pedagogical content knowledge, TPACK characterises teacher's competencies while in class teaching, by integrating technology, pedagogy, content and context knowledge under an interactive framework in addressing $21^{\text {st }}$-century learning skills (Oxford \& Graham, 1993). To this, Koehler and Mishra (2009) disseminate these key features of teacher knowledge, skills and practices. These are teaching content through technology, making use of it for teaching pedagogical knowledge, reasoning and solving learning problems using technologies to bring into the class authentic social or cultural contexts and so on. On these, scholars in line with Graham (2011) add the role of teacher's learning from interactions, coming up with new materials and technologies to be integrated into the classroom, thus developing teacher's competencies interactively in action. Some scholars, such as Archambault and Barnett (2010), also account teacher's appropriating concepts or perceptions and actions of ICT use in class as multidisciplinary educational tools known as distributed knowledge systems for designing instructions as collaborative learning practices.

In EFL education, following Koehler and Mishra's (2009) TPACK as a total package, scholars in line with Tai (2015) have extended the idea of the TPACK-in-Action-Model. Guided by this model, scholars observe developing teacher competency and the practice of ICT and/or CALL integration in EFL classroom activities, using technologies that transform language in content, concepts, approaches, skills, actions, and systems (Warschauer, 2000). As Tai (2015, p. 1) states, 'TPACK advocates learning by doing approach and it enables 
understanding EFL teachers' CALL competency and integration in EFL class in real action.' According to this model, scholars, as noted by Baser, Kopcha, and Ozden (2015), follow EFL teachers developing CALL in collaborative actions through the integration of language and media as new skills of interaction. The scholars report teachers not only making use of technologies for teaching English texts but, as Warschauer (2000) observes, practising instructions on Content and Language Integrated Learning (CLIL) or Computer Supported Collaborative Learning (CSCL) blended-learning, among other communicative approaches. Along with this stream of thought, thus, scholars, such as Ekrem and Cakir (2014) draw TPACK as an interactive framework. Within this framework, the researchers explore EFL teaching in a standard approach of building up teacher competency and practice ICT, EFL and its didactics in new forms, concepts, techniques, and skills or new social and cultural practices integrated within the classroom as a learning workshop.

Although TPACK in literature is a comprehensive concept, TE research in EFL is limited to available surveys, and in a limited fashion, either focused on observations of teacher practices or self-reported interviews; therefore, reaching out to various dimensions of teacher competence is still required (Ekrem \& Cakir, 2014). In the Czech school education context, EFL researchers considering concepts introduced by the OECD (2003) or Grečnerová (2015) express teacher competence in a mechanistic schematic rather than CALL competency on developing TPACK as a comprehensive learning framework.

Research reports, such as those by Dvorak, Urbanek, and Stary (2014), and Klimova (2015), to name a few, regard Czech school EFL teachers' CALL competency as reflecting a cognitivist model in a more standard conservative practice. Furthermore, focused research reporting teachers' CALL competency and practice in EFL classes with the TPACK-in-Action model is too sparse in the Czech school context. Moreover, as the studies are limited to teachers' perceptions and practices, teachers' reflections on collaborative actions for phenomenological transformation in teacher competences (van Lier, 1996) is a topic yet to be explored. As such, there is a gap in TPACK literature and how it is carried out in action within the realm of the Czech school context where ICT integration in EFL class is considered significant for innovating teaching practices on communication skills (Nekvapil \& Sherman, 2009).

Thus, this study integrating teachers' reflections added from the teachers' perceptions and practices is framed within the qualitative phenomenological approach design to investigate how Czech school EFL teachers develop competency and integrate ICT in teaching EFL class on developing TPACK as a transformative learning framework. 
The research questions below (RQ) are discussed for an analytical research framework base.

\section{Research Questions}

1. How do Czech elementary school EFL teachers develop competency and integrate ICT in the practice of teaching EFL class on developing TPACK -in-Action?

1.1 How do teachers perceive and reflect their competencies and practices regarding ICT integration in EFL class on developing TPACK?

2. Which practices can be represented to foster TPACK as a transformative learning framework in action?

Following these open, focused, and comprehensive research questions of reflectivity, this study aims to assert inquiries under a qualitative or descriptive phenomenological approach research design, as described below.

\section{Method}

To capture EFL teachers' teaching competences and practices of ICT integration in EFL classes on developing TPACK-in-Action as a comprehensive learning model, this study has been framed on a qualitative phenomenological approach research design borrowing from Husserl's descriptive phenomenology (Gibson, 1962). According to such a frame of analysis, as Campbell (2011a) describes, the educational phenomenon is captured on the development of subjects' experiences, such as perceptions and practices and reflections. For these purposes, Campbell suggests open interviews and observations also regarding triangulation, as the main research tools for inquiry. The open tools transcend the inquiry from what to why and how in capturing the phenomenon as developed in the subjects' personal encounters or experiences and further qualitatively interpreted by the researcher.

Following this methodology, teachers' perceptions in this study describe teachers' experiences such as perceived usefulness of ICT as external variables (Davis et al., in Eickelmann \& Vennemann, 2017), practices reveal teacher competencies in action, and reflections transformed (van Lier, 1996) what is perceived and practised on developing TPACK as a transformative learning framework.

Within this framework, thus, this study gathered data on teachers' competency and practice of ICT integration in EFL class in the process of constructing learning interactions. Open interviews and observations focused on 
teachers' perceptions, and practices and reflections were used as the main research tools. A qualitative theme analysis method was used for data analysis with triangulation and interpretation (Wajnry, 2013) on developing research subjects' TPACK-in-Action (Tai, 2015). The research participant and procedure details are as follows.

\section{Research Participants and Sampling}

As the purpose was to understand how EFL teachers in Czech elementary schools developed competency and practice technology/CALL integration in teaching EFL classroom on developing TPACK-in-Action, which essentially constructs upon individuals' working knowledge and real experiences, it was required to gather data from EFL teachers on the job with varying experiences. This is where teachers' education and ICT literacy as basic, experience in real context becomes the major variable on TPACK-in-Action as a learning-bydoing model (Tai, 2015).

To the given purpose, 12 English teachers on practices in Czech elementary schools were approached for interviews and class observations purposively followed by a snowball sampling for voluntary participation, as suggested by Saunders and Townsend (2018). The participants had distinct job experiences. The groups studied were as follows: four participants with less than five years of experience and eight participants with more than five years of job experience. In relation to education, eight participants had a master's degree in other than the English language besides some courses and training as well as informal ICT literacy. Four participants with less than five years of experience had a bachelor's degree in the English language, and despite no further training, they had attained ICT literacy through secondary school. Among the teachers, six worked in schools in the city (SiC), whereas six did in schools in towns (SiT) including two teachers from a grammar school.

\section{Data and Analysis}

With the main purpose defined as exploring and describing Czech EFL teachers' competency and practice of technology/CALL integration in the EFL classroom on developing TPACK-in- Action, teachers' personal experiences, including perceptions and practices, as well as reflections on ICT and EFL and learning interactions were studied. Based on the research questions, these listed components were focused during the open observations and interviews to generate data and further analysis such as, types of ICT used, formed and organised lessons and class activities, purposes, ways of use, functions of ICT (teacher-learner interactions, learning motivation), teachers' reflections on use 
of ICT and on EFL curriculum in class, and learning interactions.

All 12 participants were interviewed using the perception, practice, and reflection questions and a total of 24 classes, being at least at a minimum of one class and a maximum four classes, based upon relevance and availability, were observed for the qualitative monitoring of teaching with ICT in class.

The data were analysed using a qualitative theme analysis method, i.e., initial coding, theme generation, and synthesis of the findings (Flick, 2014). The findings crossed against topics were triangulated and synthesised in columns. The columns represented teacher categories in education, experiences and their school contexts followed by topics on teacher perceptions and practices and reflections that contrasted and corresponded.

The findings on similarities and differences as representative of two distinct teaching approaches, teacher's ICT, or CALL competency and practice are represented in the TPACK framework as distinguished into two main categories: 1) Formal practices defined as teacher-centred conservative model of ICT use in teaching EFL class and 2) Functional practices defined as studentcentred innovative practices of ICT use in teaching EFL class, as proposed in Lund (2003) and other studies. These categories, thus, represent sample teachers' teaching competence and practice of technology/CALL integration in EFL class as developing TPACK in two distinct models summarised in the result section below, followed by discussion and the conclusion.

\section{Results}

In this section, the two sub-heads mentioned above represent findings that describe EFL teachers' personal experiences. These are perceptions and practices, and reflections summarised following the preliminaries descriptive part below, expressing teachers' teaching competence and practice of technology or CALL integration in the EFL classroom developing TPACK-in-Action represented in two distinct models.

\section{Preliminaries}

As relevant to a study of teachers' teaching competence and practice of technology or CALL integration in EFL class, along with key findings stated later below, a few common technological systemic changes in the Czech elementary schools should be mentioned.

EFL teachers had access to ICT in EFL classes such as laptops, desktops, whiteboards, general audio-video (record) devices, sound systems, projectors, and internet and sources, mobile telephones, and both offline and internet supported 
or online, e.g., www systems, applications, information, educational material, social media communications and learning management system (LMS). Their integration into the entire curriculum as reported ranged from offline ICT $20 \%$ to $30 \%$, online $5 \%$ to $10 \%$, social media less than $5 \%$, LMS used on homework and test record purposes, and smartboard and mobiles reported as almost not used.

A common teacher perception regarding ICT in English language teaching was as expressed by the English teacher Jane ${ }^{4}$ (Interviewee 9) 'ICT are better sourced in order to teach English for communication skills to today's digital generations.' A common barrier perceived was expressed in the use of online media due to the adult content affecting child psychology and so on. In short, with such common features, an improving level of the digital education system was noted in EFL teaching that, as Tondeur et al. (2017, p. 6) explains, 'the importance of school context' could play a role as an extrinsic enabler for basic changes. This was due to, as our study found, even though contextual features did not essentially differ, teachers' competency and practice of ICT in EFL class on developing TPACK-in-Action considerably differed even within the same school context as presented in two different categories:

1. Formal practices of ICT in teaching EFL Class

2. Functional practices of ICT in teaching EFL Class

Regarding these categories, teacher practices differed on an individual basis. However, based upon some key pedagogical features, such as teachinglearning focuses, approaches, activities, ways of ICT integration, learning interactions either as grammatical or communicative skills focused (Brown, 2006), these are categorised into the two given main models on which TPACK is developed accordingly, as evidenced, discussed, and concluded below.

\section{Formal Practices of ICT in Teaching EFL Class}

In this category, findings from four participating teachers who were new to the job and two teachers with more than 15 years of experience are summarised. The findings represent teachers' perceptions, practices, and reflections regarding their competencies and practices as well as their skills integrating ICT in EFL class developing TPACK-in -Action. In this regard, these results represent teachers' formal competencies, approaches and practices of teaching EFL class and use of ICT in limited learning interactions and hence, developing a mechanistic TPACK.

4 The names of the participating EFL Teachers in this study are changed for anonymity purpose. 
One of the key components of TPACK-in-Action that determines teachers' approach to teaching and use of ICT in class is the learning focus. In this regard, as an approach to learning and teaching EFL with ICT, this group of teachers expressed communication skills. However, in practice as observed, teaching was limited with a focus on structural components of language such as word memory, grammar etc. exercises followed by other items. For instance, the participant teacher Michael (Interviewee 3 ) explained word transcriptions on a projection from an online dictionary while teaching pronunciation. Such was a common trend.

Connected to teachers' grammatical approach to teaching as a learning focus, this group of teachers in their own words viewed textbook as sufficient over other sources of materials and technologies. The teachers rationalised in the way Peter (Interviewee 8) said, 'Nowadays, these Czech books, textbooks, they have plenty of materials, or with reasons as, ... If they have the textbook, they ... have grammar section, they can study as individuals, and I think that we should promote the individual.'

With the growing priority on textbooks linked to grammatical approaches, teacher perceptions and practices of ICT in EFL classes became rather restrictive and eclipsed. In this sense, teachers were observed limitedly practising iTOOL, projector and Google devices limited in the activities such as sourcing, presenting and, eliciting information on grammatical components. For example, the teacher Juliot (Interviewee 6) asked students to choose the right form of verb displayed with the projector.

Furthermore, in association with the practices, the following teachers' reflections on uses and also the barriers of ICT were noted. Peter reflected, 'Technology is used to entertain students, but it distracts ... makes them very disorganised... is just a waste of time, you know. Similarly, George (Interviewee 2) observed, 'Technology is big, shiny [...] but after 10, 15 minutes you will find they lose attention .... Considering the online media Joseph (Interviewee 4) reflected, 'iTool has some online links but they are not very helpful,' or as Juliot expressed, 'online book [...] is not so interesting for them, a bit counterproductive.' At this point, according to the class observation, teachers who showed grammatical focus often struggled to maintain silence in class when requiring students complete grammar exercises in the textbook. Based upon this, ICT, specially online tools were spoken of as being both time consuming as well as distracting to students' attention.

Considering stimuli influence on teachers' decisions regarding the use of ICT in class, in the case of grammar-focused practices, instead of being motivational to the teacher, school and student factors were perceived as forcing the teachers to use the tools. As such, the teacher George informed, 'there are 
projectors in each class we need to use them.' Another teacher Joseph reasoned, 'you need to show students that we are also digital generations ...' Among the internal factors, teachers perceiving digital devices for students' attention could be accounted as influencing teacher decision. For instance, Michael expressed, 'iTOOL makes my lesson easier, as students become attentive...' Finally, concerning outcomes from teacher-learning interactions as another component that aids the development of TPACK-in-Action, some of the teachers expressed it limitedly, in the way Peter reported, 'I try not to take my work home which is my private life.' These teachers also reflected lack of involvement in professional courses raising CALL on TPACK competence.

In short, as the outlined features reveal, the research participants in the formal category viewed English as communicative skills; however, as stated above, teaching practices were limited to grammar. This posed difficulties for the use of ICT either limited to entertain classes or to carry out the activities such as transferring information on verbal or textual components of English. This, in turn, centralised class practices around the teacher as in ' $20^{\text {th }}$-century computer-assisted cognitive instruction' (Harasim, 2012, p. 53). In this way, considering teachers' CALL competency, despite being educated in formal digital literacy essentially to work in the networked EFL class, the participant teachers restricted ICT integration in teaching EFL psychologically to formal practices. Hence, teacher practices in the formal category have been represented as developing a mechanistic approach to TPACK in the discussion section.

In contrast, the second cohort of the teachers in this study was captured in the functional practices of settings of ICT and EFL teaching as follows.

\section{Functional Practices of ICT in EFL Class}

The second group of teachers, as exemplified in the functional practices of settings of ICT in EFL teaching, comprised six participants, ranging from five to fifteen years of job experience. The findings represent teachers' perceptions, practices, and reflections regarding teacher competencies and practices based on the integration of ICT in EFL class in constructing learning on developing TPACK-in-Action as summarised here.

Regarding the approach to EFL with ICT, the teachers in this group expressed, as Donna (Interviewee 1) asserted, 'Teaching English is for communication skills for students to learn to communicate on an international level.' Linking this learning focus, teachers interpreted that communication skills developed in EFL instructions are specially formed on cultural skills-focused activities such as comparing cultures. Arna (Interviewee 5) informed, 'We 
discuss in English, and we compare our local cultures with cultures of different countries.' This followed the analysis of teachers' EFL practices of instruction and types of ICT used. On it, teachers mentioned the lessons practised, namely CLIL, CSCL, task-based or project-based lessons. For such lessons, the English textbook, as Dave (Interviewee 7) expressed, 'was good but for the basic things only, surely not enough. These practices were significantly associated to teachers' options whether to use not only textbook and offline technologies but also online ICT in multiple instructional activities, which as Jane reported, 'integrated multiple items of students' interests.'

In association with the communication skills focus that, in turn, influenced teachers in the integration of both offline and online ICT in practising multi-thematic instructions, teachers' ways of making use of teaching materials and ICT were analysed. In this regard, it was observed that the majority of the lessons were designed on multiple integrated topics, such as science, history, environment, language, and literature. In these lessons, online media along with iTool and projectors that were perceived as being helpful were practised in blended activities, such as exploring and designing materials in the organisation of group-tasks, games, projects, and presentations by the students. These lessons were supported by the online media-based audio-visual content in English used to blend reading with listening, writing with videos, group interactions, research, etc. Thus, as Arna did, teachers in this group enabled students to use online sources to explore content, do projects and, 'make presentations.' In my observation, these instructions were prioritised in order to compensate for communication exercises in the textbook that, 'contains almost 70\% grammar', as George reported, 'Yes, to compensate this all I try to give them some writing, some reading, then listening combined.'

Following such practices, teachers expressed their reflections relating ICT use in the EFL curriculum in class and learning interactions in individual ways. However, on these matters, both offline and online technologies were interpreted as useful for engaging students in learning activities with a communication skills focus. In this regard, the teachers reflected ICT emphasising online media as promoting the use of English, presentation skills, interactive assessment and project learning practices in class. For instance, Arna reflected, 'We discuss things in English for which online media help a lot.' Similarly, Dave expressed, 'Students involve on multimedia presentations with higher learning motivation.' Relating ICT for interactive assessments Donna reflected, 'I mark projects that students do with the help of online sources.' Likewise, the online media were reflected useful on group-projects in which students use technologies in tasks for teachers engaged on monitoring or in facilitative roles. 
As, Arna said, 'There are many projects and presentations we do as supported by media.' Dave reported, 'We have online exercises, and I just go and look through on what they are doing.'

In short, following the findings outlined, teachers' perceptions, practices and reflections considering teacher's competency and integration of technology or CALL in EFL class in the functional category are significantly interactive vis-à-vis the formal category. In this category, teachers exhibited growing reflectivity along with increasing learning interactions and that, in effect, related to fostering teachers' CALL competency. In this connection, as the teacher reports inform, apart from the use of typical materials, in teachers' interacted practices, use of ICT was reflected for inventing new materials, tasks, skills in increasing learning by actions, collaboration, and reflections. Teachers in this category also reported themselves as being involved on several training courses raising new competencies, as stated by Dave, 'I attend lot training courses to develop my competence.' In this way, in practical terms, the research participants in the functional category, along with expressing interactive approaches to EFL also expressed interactively developing technology or CALL competency on developing transformative TPACK-in-Action as represented in the discussion section that follows.

\section{Discussion}

In the view of fast-paced digital school education teaching-learning systems, the usefulness of TPACK-in-Action is in developing subject teachers' media and didactic competences and practices. This in innovative learning processes as shown in Koehler \& Mishra (2009) has significant effect for better student learning. Thus, following TPACK as a comprehensive learning framework on phenomenolgical (social) construction, this study investigated, Czech elementary school EFL teachers' approaches and practices of ICT in teaching EFL. In it, teachers' perceptions, practices, and reflections regarding their technology or CALL competency and practice of integration in EFL classroom, expressing TPACK in the findings are grouped into two categories labelled as:

1. formal practices of ICT in EFL class, and

2. functional practices of ICT in EFL class.

The first category represents EFL teaching practiced on grammatical models whereas the second category represents teaching practiced on communicative approaches. These, as paradigmatically elucidated in Richards and Rodgers (2014), are cognitivist and (social) constructivist educational models, and accordingly express teachers' technology or CALL competency and 
practice linking the development of TPACK-in-Action (Tai, 2015).

Distinguished in pedagogical parameters, the results on teachers' practices synthesised in the two categories support Tondeur et al.s (2017) findings that teachers make use of technologies in classrooms in different paradigmatic models. However, this is majorly determined by teachers' individual definitions of learning, approaches, and teaching practices and likewise, integrating technologies to developing TPACK in individual ways. In this study, this is supported by the fact that the different individual participants in regard to ICT in teaching EFL classes expressed conservative opinions in grammar focus. Furthermore, teachers' perceptions, practices, and reflections regarding ICT in class on communicative skills focus differed amongst individual participants even within the same school context, albeit their approaches to ICT and EFL in the functional category interacted significantly.

At this point, when other elements, such as context factors as claimed by Tondeur et al. (2017) were involved, teachers' individual perceptions, practices, and reflectivity played a greater role on how the teachers developed competencies and practices of ICT and/ or CALL integration in real working contexts. Thus, taking these features into consideration, this study, in line with Tai (2015), claims that in action, teachers' TPACK, in reality, poses differences from the literature. That is, it is developed on behaviourist, cognitivist, constructivist and other models that the individual teachers tend to practice. This is evidenced in this study from sample EFL teachers who expressed competency and practice of technology or CALL in EFL classroom activities using different individual models. However, taking a few pedagogical components into account, as expressed in terms of learning focus and interaction with ICT in class among some others, two distinct models are distinguished: a mechanistic one and, in contrast, a transformative TPACK-in-Action as discussed below. As such, the discussions answer the research question as to 'Which practices can be represented to foster TPACK as a transformative learning framework?' In this regard, functional practices are represented developing TPACK as a transformative learning model. The first part of the discussion on formal practices represents mechanistic TPACK followed by the discussion related to functional practices representing transformative TPACK as follows.

Assessed from the pedagogical perspective, teacher practices as synthesised in the category of formal practices in this study act in accordance with Richard and Rodgers's (2014) concept that the approach to teaching grammar in EFL classes using formal instructions builds an emphasis on the knowledge aspects of language. With growing emphasis on the knowledge aspects, teachers limit themselves to designing structurally centralised instructions. These, however, 
prevent teachers from integrating multiple interrelated aspects such as, new concepts, contexts, technologies, and media that can build language in association with communication skills. In such teacher centralised practices, as Burston (2014) found, the teaching materials and technologies not so prioritised are the least integrated. Likewise as Chang (2011) reported, teachers limited to practising knowledge transmitting instructions, make up the fewest learning interactions in which TPACK is accounted as limited. In this study, though teachers in the formal category also ascribed EFL for communication skills, their actions expressed learning in terms of acquiring knowledge of grammar. This limited classes to English textbook forcing students to memorise the English texts to pass exams. It identically resulted in limited practice and acquisition of language skills and of technologies confined to iTOOL used for information on grammatical problems. Furthermore, in the category of formal practices teachers did not try to develop new teaching-learning materials or technologies beyond textbooks, nor did they become involved in learning courses. Therefore, teacher-learning interactions on raising CALL competency were limited in these practices.

From the TPACK-in-Action perspective, following Tai (2015), teachers and their colleagues develop competency and practice of technologies in actions based upon learning-by-doing collaborations. In this model, technology integration is for designing instructions on multi-disciplinary themes constructing language in skills and contexts, thus increasing learning interactions. Taken from these criteria, the research participants in the formal category expressing structural elements of EFL also expressed technology in its mechanistic forms and for limited purposes and practices. As such, their expressions limited TPACK to mechanistic development. For instance, whereas various media were accessible, the participants in the formal group limited their focus to English textual components for which the ICT presentation tools, as one example, along with textbooks were repeatedly integrated into the class to disseminate information.

On a reflective part of the teacher, as van Lier (1996) finds, EFL teaching in interactive approaches increases future reflective actions that either develop teacher competency and practice of new teaching technology on a regular construction developing transformative TPACK in EFL class. However, the teachers in the formal category, apart from being sceptical in their perceptions, reflected technologies basically limited to, as Warshauer (2000) mentions, fill-in cognition rather than constructing learning, and they expressed low learning-interactions. In this way, with structurally confined features, teachers' technology or CALL competency, and practice in the EFL classroom on limited learning interactions leading to mechanistic learning outcomes are described in Figure 1. 


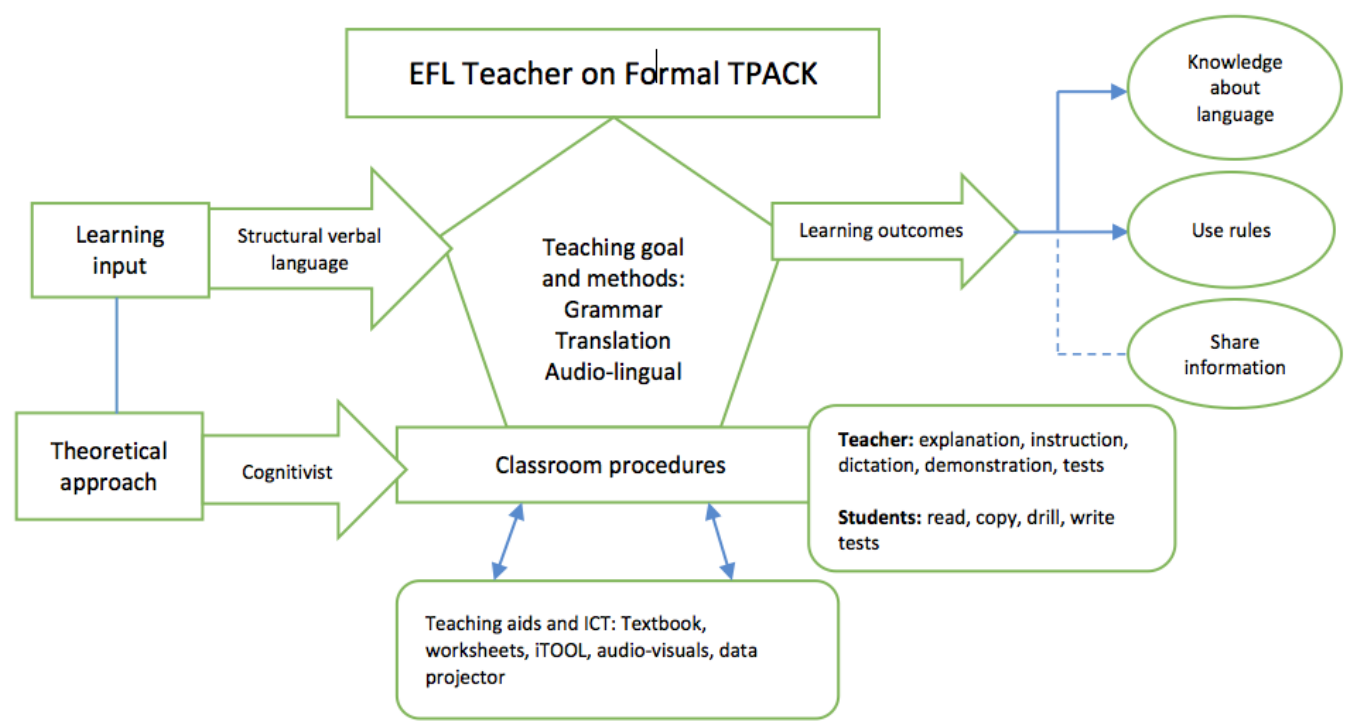

Figure 1. Czech elementary school EFL teachers in formal practice of ICT in EFL class developing formal or mechanistic TPACK.

As the figure represents, EFL teachers on using ICT in formal practices that are limited to transmitting grammatical components of language are represented developing formal or mechanical TPACK-in-Action.

In contrast, the EFL teachers categorised in the functional practices in this study are exemplified in teaching competence and practice of ICT and/or CALL integration in EFL class framing instructions as collaborative learning models as developing transformative TPACK-in-Action.

Teacher practices synthesised in the functional category are in alignment with Brown's (2006) concept that teachers in communicative approaches practice functional instructions with an emphasis on language for communication skills. In communication skills-focused instructions, Godwin-Jones (2010) describes EFL teachers integrating technology/ CALL in class interactively for learning purposes. With an emphasis on communication skills, it is mentioned that EFL teacher practices collaborative learning methods such as Warschauer (2000), among others, reports CLIL, CSCL or blended-learning instructions on this scheme. In this study, teachers in the functional category expressed and practised mostly group-participated task-based instructions usually mediated by offline and online technologies. In such practices, as also noted by Tai (2015), the teachers integrated learning content as a key knowledge component of TPACK not merely in English texts but also in English that embedded multisubject and cultural themes, media, and systems. 
A pedagogical component in van Lier's (1996) framework enables the EFL teacher to design instructions that actively engage students, mediated by the teacher, with new technologies. In this study, the EFL teachers in the functional category designed participatory task-based instructions engaging students to construct language using offline and online ICT when solving problems. Apart from it, there is a technological component of TPACK. In this regard, these participants are captured using technologies, as in Buabeng-Andoh's (2012) study, not just based on structural devices used by the teacher for information with the data-projector but also using media tools providing learners with mutually shared learning opportunities and growth in self-efficacy.

At this point, functional teachers in this study also added a transformative element to their CALL competency on TPACK as indicated by teachers' increased reflectivity. This was evidenced in the reflective interviews. In these post-teaching interviews, the participant teachers in the functional category agreed, as also expressed in van Lier's (1996) finding in which it says that technologies are enriching learning tools to regularly improve, invent, and integrate new materials, ideas and skills in the EFL class on (social) construction of language. According to this functional model, the EFL teacher uses technologies to construct language through learners' awareness, autonomy and authenticity and learners' intrinsic motivation. In this way, based on interactive features of teacher competency and practices, as stated, the participant EFL teachers involved in functional practices are represented by developing TPACK-in-Action as a transformative learning framework as concluded below.

In interactive teacher practices, this study represents functional learning features that increase learner creativity potential, also described in Figure 2. 


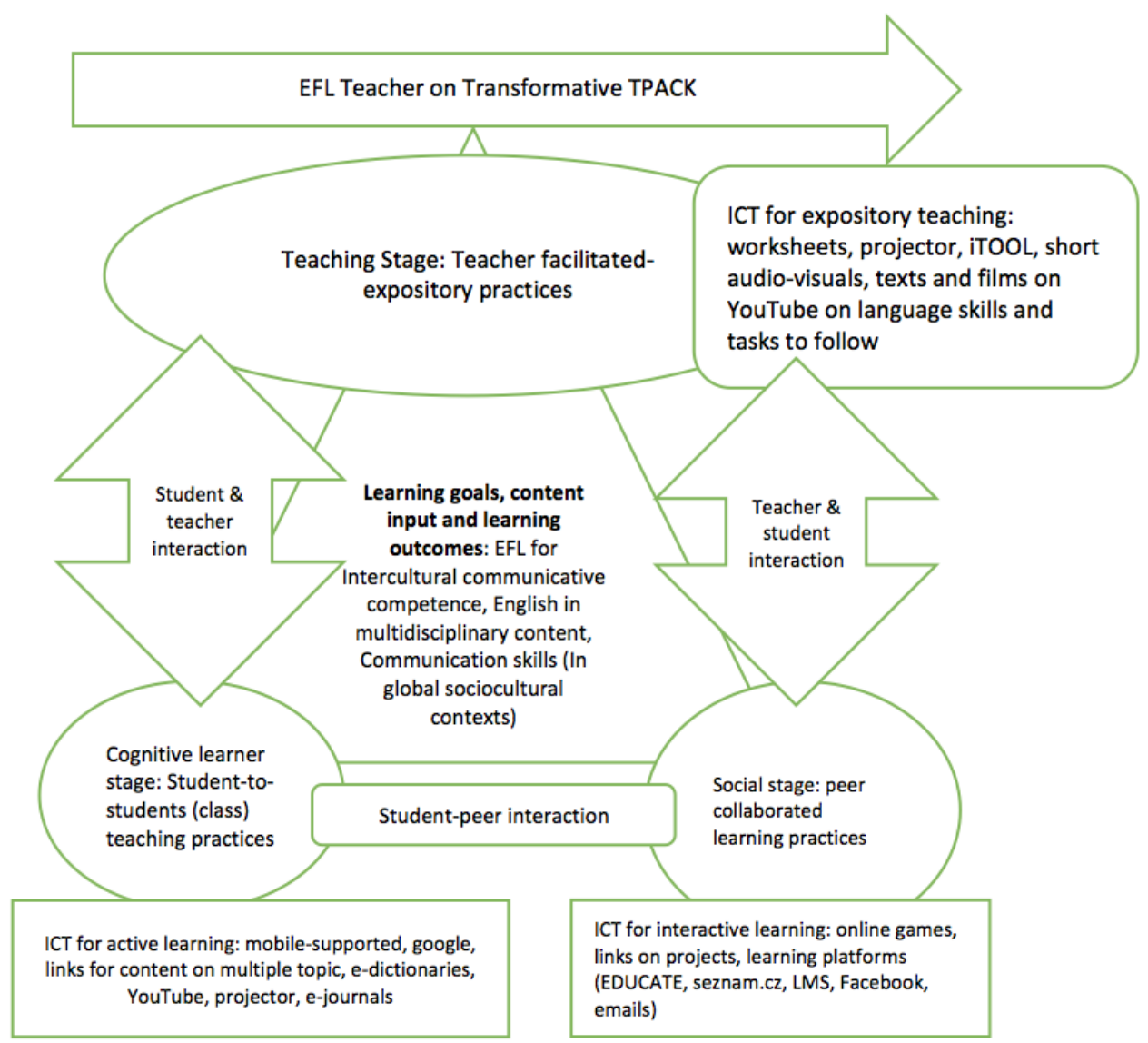

Figure 2. Czech elementary school EFL teachers in functional practices of ICT in EFL class on the development of transformative TPACK.

As the figure represents, the sample EFL teachers in functional practices integrate interactive technology or CALL features in the student-centred collaborative skills learning instructions on developing TPACK as a transformative learning framework.

\section{Conclusion}

Regarding the Czech elementary school EFL teachers' teaching competence and practice of technology or CALL integration in EFL class on developing TPACK-in-Action as a transformative learning framework, this study brings the argument in line with that of Drossel, Eickelmann, and Schulz-Zander (2017). It is that teachers with interactive digital pedagogical educational background 
and experience, as opposed to those with a formal technological education, develop comprehensive TPACK and integrate it into EFL classes in significant and interactive ways. This finding contributes to the literature on teacher competence that says that teachers with (social) constructivist backgrounds and perspectives develop didactic practices such as EFL teaching as innovative learning processes (Godwin-Jones, 2010). On interactive backgrounds, teachers not only assert technological competency from acquired formal education to practice teaching in globally networked classes but also construct practices in 'stretching the mould' (Collis \& Gommer, 2001 in Selwyn, 2011) for better student learning. In this study, better student learning in EFL within the emerging European context relates to teaching innovations in addressing communicative skills for global citizens (Byram, 2008), for which Czech EFL teachers in functional practices of teaching with ICT are positively represented.

\section{Acknowledgement}

The paper is part of the European Doctorate in Teacher Education (EDiTE) project that has received funding from the European Union's Horizon 2020 research and innovation programme under Marie Sklodowska-Curie grant agreement number 676452 .

\section{References}

Archambault, L. M., \& Barnett, J. H. (2010). Revisiting technological pedagogical content knowledge: Exploring the TPACK framework. Computers and Education, 55(4), 1656-1662.

Baser, D., Kopcha, T. J., \& Ozden, M. Y. (2016). Developing a technological pedagogical content knowledge (TPACK) assessment for preservice teachers learning to teach English as a foreign language. Computer Assisted Language Learning, 29(4), 749-764.

Brown, H. D. (2006). Principles of language learning and teaching. New York, NY, \& London, UK: Routledge.

Buabeng-Andoh, C. (2012). An exploration of teachers' skills, perceptions and practices of ICT in teaching and learning in the Ghanaian second-cycle schools. Contemporary Educational Technology, $3(1), 36-49$.

Burston, J. (2014). MALL: The pedagogical challenges. Computer Assisted Language Learning, 27(4), $344-357$.

Byram, M. (2008). Languages for intercultural communication and education: From foreign language education to education for intercultural citizenship: Essays and reflections. Clevedon, UK, Buffalo, NY, \& Toronto, CA: Multilingual Matters.

Campbell, J. (2011). Introductive methods to qualitative research. Retrieved from www.staff.vu.edu. 
au.syed/alrnnv/papers/bev.html

Chang, S. (2011). A contrastive study of grammar translation method and communicative approach in teaching English grammar. Computer Assisted Language Learning, 4(2), 13-24.

Dockstader, J. (1999). Teachers of the $21^{\text {st }}$ - century know the what, why, and how of technology integration. Technological Horizons in Education Journal, 26(6), 73-74.

Drossel, K., Eickelmann, B., \& Schulz-Zander, R. (2017). Determinants of teachers' collaborative use of information and communications technology for teaching and learning: A European perspective.

European Educational Research Journal, 16(6), 781-799.

Dvorak, D., Urbanek, P., \& Stary, K. (2014). High autonomy and low accountability: Case study of five Czech schools. Pedagogická Orientace, 24(6), 919-940.

European Doctorate in Teacher Education (EDiTE). (2015). Transformative teacher learning for better student learning within the emerging European contexts. Retrieved from http://www.edite.euhttp:// www.edite.eu/

Eickelmann, B., \& Vennemann, M. (2017). Teachers' attitudes and beliefs regarding ICT in teaching and learning in European countries. European Educational Research Journal, 16(6), 733-761.

Ekrem, S., \& Cakir, R. (2014). Examining preservice EFL teachers' TPACK competencies in Turkey. Amasya University, 1(1), 1-22.

Flick, U. (2014). Three approaches to qualitative data analysis introduction. In U. Flick (Ed.), The SAGE handbook of qualitative data analysis (pp. 1-13). Los Angeles, CA, London, UK, New Delhi, Singapore, \& Washington, DC: Sage.

Godwin-Jones, R. (2010). Emerging technologies literacies and technologies revisited. Language Learning and Technology, 14(3), 2-9.

Graham, C. R. (2011). Theoretical considerations for understanding technological pedagogical content knowledge (TPACK). Computers \& Education, 57(3), 1953-1960.

Grecnerova, B. (2015). European schoolnet. Czech Republic Country Report on ICT in Education. Brussels: Centre for International Cooperation in Education. Retrieved from http://www.eun.org/ observatory

Harasim, L. (2012). Learning theory and online technologies. New York, NY, \& London, UK: Routledge. Husserl, E. (1913). Ideas: General introduction to pure phenomenology (W. R. Boyce Gibson, Trans.). London, UK, \& New York, NY: Collier, Macmillan. Retrieved from http://www.greenboarstudio.com/ uploads/2010_02_04_Husserl_Ideas_Crisis_of_Philosophy_Introduction_to.pdf

Klimova, B. (2015). A corpus-based approach to the teaching of English. In G. Lee \& G. Schaefer (Eds.), Proceedings from 4 th International conference on social sciences and society. Bellflower, CA: Information Engineering Research Institute.

Koehler, M. J., \& Mishra, P. (2009). What is technological pedagogical content knowledge. Contemporary Issues in Technology and Teacher Education, 8(1), 60-70.

Lund, A. (2003). The teacher as interface: Teachers of EFL in ICT-rich environments. Beliefs, practices, appropriation. Unpublished doctoral dissertation. Skien/Oslo: The University of Oslo.

Nekvapil, J., \& Sherman, T. (2009). Czech, German and English: Finding their place in multinational 
companies in the Czech Republic. In P. Carl \& J. Stevenson (Eds.), Language discourse and identity in Central Europe: The German language in multilingual space (pp. 122-146). Basingstoke, UK: Palgrave Macmillan.

OECD. (2003). Literacy skills for the world of tomorrow: Further results from PISA 200o. Montreal, CA: UNESCO Institute for Statistics.

Oxford, R. L., \& Graham, M. (1993). Language learning strategies: What every teacher should know. TESOL Quarterly, 27(1), 121-122.

Richards, J. C., \& Rodgers, T. S. (2014). Approaches and methods in language teaching. Cambridge, UK: Cambridge University Press.

Saunders, M. N. K., \& Townsend, K. (2018). Choosing participants. In C. Cassel, A. L. Cunliffe, \& G. Grandy (Eds.), The Sage handbook of qualitative business and management research methods (pp. 480-494). Los Angeles, CA, London, UK, New Delhi, Singapore, Washington, DC, \& Melbourne: Sage Publications.

Schratz, M. (2014). The European teacher: Transnational perspectives in teacher education policy and practice. Central European Journal of Public Policy, 4(4), 11-27.

Selwyn, N. (2012). Education and technology: New issues and debates. London, UK, \& New York, NY: Continuum International Publishing Group.

Stensaker, B., Maassen, P., Borgan, M., Oftebro, M., \& Karseth, B. (2007). Use, updating and integration of ICT in higher education: Linking purpose, people and pedagogy. Higher Education, 54(3), 417-433. Tai, S.-J. D. (2015). From TPACK-in-action workshops to classrooms: CALL competency developed and integrated. Language Learning \& Technology, 19(1), 139-164.

Tondeur, J., Braak, J. van, Ertmer, P. A., \& Ottenbreit-Leftwich, A. (2016). Understanding the relationship between teachers' pedagogical beliefs and technology use in education: A systematic review of qualitative evidence. Journal of Educational Technology Research and Development, 65(3), 555-575.

Tour, E. (2015). Digital mindsets: Teachers' technology use in personal life and teaching. Language Learning \& Technology, 19(193), 124-139.

van Lier, L. (1996). Interaction in the language curriculum: Awareness, autonomy and authenticity. London, UK: Longman.

Wajnryb, R. (2013). Class observation tasks: A resource book for language teachers and trainers. Cambridge, UK, \& New York, NY: Cambridge University Press.

Warschauer, M. (2000). The changing global economy and the future of English teaching. TESOL

Quarterly, 34(3), 511-535. 


\section{Biographical note}

Dev Raj PAneru is a researcher in the area of foreign language teacher education under the European Doctorate in Teacher Education (EDiTE) as part of the European Commission's Horizon 2020 Initiative, affiliated with the Department of Educational Sciences of the Faculty of Arts at Masaryk University, Brno, The Czech Republic. His research interests include exploring the communicative and innovative pedagogical dimensions of language teaching and technology that are effective in enhancing 21st-century teacher skills that align with a broad-based vision articulated as transformative teacher learning for better student learning in emerging global and European contexts. 